\title{
Pengaruh campuran bahan bakar minyak plastik dan premium terhadap prestasi mesin sepeda motor
}

\author{
Arif Permadi ${ }^{1}$, Untung Surya Dharma ${ }^{2}$, Dwi Irawan ${ }^{3}$ \\ ${ }^{1}$ Prodi Teknik Mesin, Fakultas Teknik, Universitas Muhammadiyah Metro \\ Jl. Ki Hajar Dewantara 15 A Kota Metro, Lampung, Indonesia \\ 2,3Jurusan Teknik Mesin, Fakultas Teknik, Universitas Muhammadiyah Metro \\ Jl. Ki Hajar Dewantara 15 A Kota Metro, Lampung, Indonesia \\ ${ }^{\star}$ Corresponding author: untungsdh@yahoo.co.id
}

\begin{abstract}
Energy consumption is currently relatively large resulting in increased prices of fossil fuels and reduced distribution in every island in Indonesia. A mixture of plastic and premium oil is an alternative fuel in controlling the current energy crisis. The purpose of this study was to determine the maximum output power of a motorcycle, torque and acceleration. In the power measurement method, every increase in rotation is from 2000,3000, 4000, 5000 and $6000 \mathrm{rpm}$, in the acceleration test, measurements are made at speeds of 20,40,60, 80 and $100 \mathrm{~km} / \mathrm{h}$, with mixed variables 1:4, 2: 4 and 3:4, as well as comparing the results with premium fuels. As a result, mixture 1 produces power, torque and acceleration better than mixture 2 and mixture 3. The power produced is $7.88 \mathrm{~kW}$ with a specific fuel of $0.091 \mathrm{~kg} / \mathrm{hour} / \mathrm{kW}$, torque of 12.55 $\mathrm{Nm}$, the highest acceleration or acceleration is $5,52 \mathrm{~m} / \mathrm{s} 2$ by consuming 0.25 liters of fuel, while the premium power produced is $8.1 \mathrm{~kW}$ with a specific fuel of $0.09 \mathrm{~kg} / \mathrm{hour} / \mathrm{kW}, 12.9 \mathrm{Nm}$ of torque, and the highest acceleration of $5.45 \mathrm{~m} / \mathrm{s} 2$ with fuel consumption of 0.25 liters. So it is stated that the value of power, torque and acceleration in mixture 1 is still below premium fuel, but mixture 1 has a better efficiency level than premium fuel.
\end{abstract}

Keywords: Mix 1, power, torque, acceleration

Abstrak

Konsumsi energi saat ini tergolong besar mengakibatkan meningkatnya harga bahan bakar fosil serta berkurangnya distribusi disetiap pulau diindonesia. Campuran minyak plastik dan premium merupakan alternatif bahan bakar dalam mengendalikan krisis energi yang saat ini terjadi. Tujuan penelitian ini adalah untuk mengetahui maksimal daya keluaran sepeda motor, torsi dan akselerasi. Dalam metode pengukuran daya dilakukan setiap kenaikan putaran yaitu dari 2000, 3000, 4000, 5000 dan $6000 \mathrm{rpm}$, pada uji akselerasi dilakukan pengukuran pada kecepatan 20, 40, 60, 80 dan $100 \mathrm{~km} / \mathrm{h}$, dengan variabel campuran 1:4, 2:4 dan 3:4, serta dilakukan pembandingan hasil dengan bahan bakar premium. Hasilnya, campuran 1 menghasilkan daya, torsi dan akselerasi lebih baik dari campuran 2 dan campuran 3. Daya yang dihasilkan adalah $7,88 \mathrm{~kW}$ dengan bahan bakar spesifik $0,091 \mathrm{~kg} / \mathrm{jam} / \mathrm{kW}$, torsi $12,55 \mathrm{~N} . \mathrm{m}$, Akselerasi atau percepatan tertinggi $5,52 \mathrm{~m} / \mathrm{s}^{2}$ dengan menghabiskan bahan bakar sebanyak 0,25 liter, sedangkan daya yang dihasilkan premium ialah $8,1 \mathrm{~kW}$ dengan bahan bakar spesifiknya $0,09 \mathrm{~kg} / \mathrm{jam} / \mathrm{kW}$, torsi $12,9 \mathrm{~N} . \mathrm{m}$, dan percepatan tertinggi $5,45 \mathrm{~m} / \mathrm{s}^{2}$ dengan konsumsi bahan bakar 0,25 liter. Sehingga dinyatakan bahwa nilai daya, torsi dan akselerasi pada campuran 1 masih dibawah bahan bakar premium, namun campuran 1 memiliki tingkat efisiensi lebih baik dari bahan bakar premium.

Kata Kunci : Campuran 1, daya, torsi, akselerasi

\section{Pendahuluan}

Kelangkaan bahan bakar premium yang terjadi belakangan ini telah memberikan dampak yang sangat luas diberbagai sektor kehidupan. Sektor yang paling cepat terkena dampaknya adalah 
sektor transportasi. Di samping hal tersebut, penggunaaan bahan bakar dari minyak bumi telah memberikan dampak negatif terhadap lingkungan. Fluktuasi suplai dan harga minyak bumi seharusnya membuat kita sadar bahwa jumlah cadangan minyak yang ada di bumi semakin menipis. Karena minyak bumi adalah bahan bakar yang tidak bisa diperbarui maka kita harus mulai memikirkan bahan penggantinya. Untuk itulah dibutuhkan suatu energi alternatif yang ramah lingkungan sebagai bahan bakar motor bakar, salah satu diantara energi alternatif itu adalah Minyak dari plastik. Minyak plastik ini terbuat dari sampah Plastik dengan metode pirolisis [1].

Perlunya peninjauan mengenai uji aplikasi terhadap sepeda motor, yang memungkinan minyak tersebut berpengaruh dengan kerja mesin. Motor bakar bensin merupakan motor dengan pembakaran dalam. Pembakaran merupakan reaksi kimia cepat antara oksigen dan bahan bakar pada suhu tertentu, yang disertai pelepasan kalor.

Untuk keamanan serta kenyamanan saat pengujian, diperlukan bahan bakar lainnya sebagai campuran untuk kedua faktor penting tersebut. Selain untuk keamanan dan kenyamanan, faktor lain yang mempengaruhi ialah penyesuaian mesin terhadap bahan bakarnya. Beberapa alasan tersebut perlu dipertimbangkan, untuk menghindari terjadinya kerusakan apabila bahan bakar tersebut tidak layak atau belum bisa digunakan pada sepeda motor. Percampuran tersebut harus dilakukan secara bertahap, agar diketahui kemampuan maksimal bahan bakar dalam menciptakan tenaga pada sepeda motor. Tujuan daripada penelitian ini adalah untuk mengetahui kemampuan bahan bakar campuran dalam menghasilkan torsi, daya dan akselerasinya.

\section{Tinjauan Pustaka}

Bahan Bakar Minyak Plastik

Plastik adalah material rekayasa yang struktur molekulnya memiliki komposisi yang rumit, yang sengaja diatur untuk memenuhi aplikasi - aplikasi spesifik sesuai dengan keinginan. Dengan kata lain plastik merupakan gabungan antara polimer dan zat aditif. Polimer secara umum tersusun dari unsur atom karbon, oksigen dan hidrogen. Unsur - unsur atom tersebut merupakan unsur atom yang mendekati sama dengan unsur atom dari bahan bakar yang terdiri dari karbon dan hidrogen. Sehingga hanya diperlukan serangkaian proses penguraian kembali dengan suatu metode khusus untuk membuat bahan bakar tersebut [2].

\section{Motor Bakar}

Motor bakar adalah suatu pesawat yang digunakan untuk merubah energi kimia bahan bakar menjadi energi panas (termal), dan menggunakan energi tersebut untuk melakukan kerja mekanik.

1. Tekanan efektif rata-rata [3]

$P_{e}=\frac{N_{e} \times 60 \times 10^{5}}{V_{l .} \text { Z.n. a }}$

Dimana :

$P_{e}$ : Tekanan efektif rata - rata

$\left(\mathrm{N} / \mathrm{cm}^{2}\right)$

$N_{e}$ : Daya efektif (kW),

$V_{l}$ : Volume langkah torak $\left(\mathrm{cm}^{3}\right)$,

$Z$ : Jumlah silinder,

a : Jumlah siklus per putara

(1 untuk motor dua langkah

dan

2 untuk motor empat langkah)

2. Daya efektif [4]

$N_{e}=\frac{2 \pi \times n \times T}{60}$

Dimana :

$T$ : Torsi (N.m),

$N_{e}$ : Daya efektif dinyatakan dalam $\mathrm{kW}$.

$n$ : Putaran mesin (rpm)

3. Torsi [5]

$T=F . r$

Dimana :

$T$ : Torsi (N.m)

$F$ : aya yang diberikan $(N)$

$r:$ Jari - jari atau jarak titik gaya $(m)$.

4. Akselerasi [6]

$a=\frac{\Delta v}{\Delta t}$ 
Dimana :

$a$ : Akselerasi $\left(\mathrm{m} / \mathrm{s}^{2}\right)$

$\Delta v:$ Perubahan kecepatan $(\mathrm{m} / \mathrm{s})$

$\Delta t$ : Waktu yang dibutuhkan untuk menempuh kecepatan tersebut

5. Pemakaian bahan bakar [6]

a. Pemakaian bahan bakar

$B=\frac{\rho_{b b} \cdot V}{t} \times 3600$

Dimana :

$B$ : Pemakaian bahan bakar $(\mathrm{kg} / \mathrm{j} \mathrm{m})$,

$\rho_{b b}$ :Massa jenis bahan bakar $\quad(\mathrm{kg} / \mathrm{l})$

$V$ : Volume bahan bakar dalam liter $(l)$,

$t$ : Waktu yang diperlukan untuk menghabiskan bahan bakar dalam detik $(s)$.

Untuk mencari massa jenis $\left(\rho_{b b}\right)$, menggunakan persamaan berikut : [7]

$\rho_{b b}=\frac{M_{b b}}{V_{b b}}$

Dimana :

$\rho_{b b}$ : Massa jenis bahan bakar $(\mathrm{kg} / \mathrm{l})$,

$M_{b b}$ : Massa bahan bakar $(\mathrm{kg})$,

$V_{b b}$ : Volume bahan bakar yang diukur dalam liter $(l)$.

b. Pemakaian bahan bakar spesifik [3]

$b e=\frac{B}{N_{e}}$

Dimana :

be : Pemakaian bahan bakar spesifik $\left(\frac{\mathrm{kg} / \mathrm{jam}}{\mathrm{kW}}\right)$,

$B$ : Pemakaian bahan bakar $(\mathrm{kg} / \mathrm{jam})$,

$N_{e}$ : Daya efektif $(\mathrm{kW})$.

\section{Metode Penelitian}

\section{Prosedur penelitian}

Adapun sepeda motor yang digunakan pada penelitian ini adalah sebagai berikut.

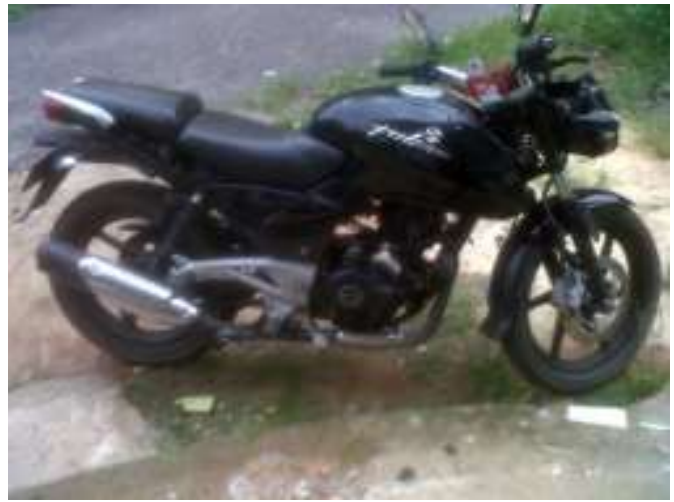

Gambar 1. Sepeda Motor Bajaj Jenis Pulsar 180 DTS- $i$

Spesifikasi teknis sepeda motor tersebut disajikan pada uraian berikut ini.

Isi silinder

$: 179,8 \mathrm{~cm}^{3}$

Diameter

: $63,50 \mathrm{~mm}$

Langkah

: $56,40 \mathrm{~mm}$

Tekanan pembakaran : $98 \mathrm{~N} / \mathrm{cm}^{2}$

Torsi maksimum: 15,22 Nm at $6000 \mathrm{rpm}$

Tenaga maksimum : $12.15 \mathrm{~kW} \pm 10 \%$ @ $8000 \mathrm{rpm}$

\section{Bahan penelitian}

Adapun bahan penelitian menggunakan tiga variabel yakni :

1. Perbandingan $1: 4(\mathrm{C} 1)$

2. Perbandingan $2: 4(\mathrm{C} 2)$

3. Perbandingan $3: 4(\mathrm{C} 3)$

Premium memiliki variabel tetap, sedangkan minyak plastik memiliki variabel yang tidak tetap. Berikut propertis minyak plastik 2 kali pirolisis.

Tabel 1. Sifat kimia fisik minyak plastik dua kali pirolisis

\begin{tabular}{cccc}
\hline Parameter & HDPE & LDPE & HDPE+LDPE \\
\hline $\begin{array}{c}\text { NK } \\
\mathrm{Kkal} / \mathrm{kg}\end{array}$ & 10968 & 10839 & 10516 \\
\hline $\mathrm{KA}(\mathrm{g} / \mathrm{l})$ & - & - & 0,1122 \\
\hline CI & 50 & 54 & 20 \\
\hline
\end{tabular}

Sumber : [2]

\section{Tahapan Penelitian}

1. Tahap pertama, pengadaan alat dan bahan sesuai pada peralatan yang telah disebutkan. Pada tahap pertama ini juga melakukan kegiatan instalasi peralatan yang telah disetting sebelumnya, yaitu meliputi pemasangan tachometer digital dan botol selang infus. 
2. Tahapan kedua adalah mengukur massa jenis tiap - tiap campuran, cara pengukuran massa jenis ialah dengan menimbang bahan bakar campuran pada volume 1 liter. Kemudian hasil tersebut dikalkulasi dengan cara dikurangi massa wadahnya.

\section{Uji Aplikasi}

1) Uji performa sepeda motor menggunakan bahan bakar premium meliputi :

a. Menghidupkan mesin dengan putaran idle berkisar antara $850 \mathrm{rpm}$, menaikkan putaran sesuai yang diinginkan, kemudian lakukan pembebanan dengan cara menginjak pedal rem belakang yang sudah terpasang neraca pegas. Pembebanan ini dilakukan bertahap dari 5\% sampai $40 \%$ hingga roda belakang sepeda motor berhenti dan mencatat data - data pembebanan pada putaran tertentu. Dengan variabel putaran mesin 2000, 3000, 4000, 5000 dan 6000 rpm. Supaya putaran menjadi lebih ringan, kondisi pengujian tersebut di lakukan pada top gear. Dengan tenggang waktu masing masing putaran yaitu selama 10 menit.

b. Melakukan pencatatan komsumsi bahan bakar, hal ini bertujuan untuk mengetahui pemakaian bahan bakar pada pengujian tersebut.

c. Pengujian ini dilakukan 3 kali, per kenaikan putaran (pada poin a dan b). Dengan ketentuan temperatur awal ruang bakar yang sama pada pengujian awal serta waktu yang sama.

2) Selanjutnya adalah uji akselerasi, tujuan uji ini untuk mengetahui respon mesin terhadap bahan bakar yang digunakan dengan parameter kecepatan, konsumsi bahan bakar habis dan waktu yang diperlukan, diluar konteks dari spesifikasi pabrikan mesin sepeda motornya. Metode pengujian akselerasi ini dilakukan dengan cara memacu sepeda motor pada lintasan lurus, dengan variabel kecepatan $20 \mathrm{~km} / \mathrm{jam}, \quad 40$ $\mathrm{km} / \mathrm{jam}, 60 \mathrm{~km} / \mathrm{jam}, 80 \mathrm{~km} / \mathrm{jam}$ dan 100 $\mathrm{km} / \mathrm{jam}$ dan berjalan konstan dengan jarak $2 \mathrm{~km}$. Mencatat waktu yang diperlukan sepeda motor untuk mencapai kecepatan tersebut menggunakan stopwatch (keadaan diam - kecepatan yang ditentukan), setelah kecepatan tersebut tercapai kemudian memacu kendaraan dengan kecepatan konstan sesuai pada variabel kecepatannya. Kecepatan konstan diperlukan untuk menentukan konsumsi bahan bakarnya, dengan asumsi bahwa konsumsi bahan bakar dinyatakan dalam rata - rata pemakaian setiap kecepatannya dianggap sama.

Uji performa sepeda motor menggunakan bahan bakar campuran premium dan minyak dari plastik dengan menggunakan metode yang sama saat menggunakan bahan bakar premium.

\section{Hasil dan Pembahasan}

Tabel 2. Massa jenis campuran miplas dan premium

\begin{tabular}{cc}
\hline $\begin{array}{c}\text { Perbandingan } \\
\text { Campuran } \\
\text { (Miplas : Premium) }\end{array}$ & $\begin{array}{c}\text { Massa jenis } \\
\rho(\mathrm{kg} / \mathrm{l})\end{array}$ \\
\hline $1: 4$ & 0,804 \\
\hline $2: 4$ & 0,815 \\
\hline $3: 4$ & 0,832 \\
\hline Premium & 0,711 \\
\hline
\end{tabular}

Tabel 2 di atas didapatkan menggunakan pengukuran langsung. Adapun menurut penelitian, hasil prestasi disajikan sebagai berikut.

\section{Torsi}

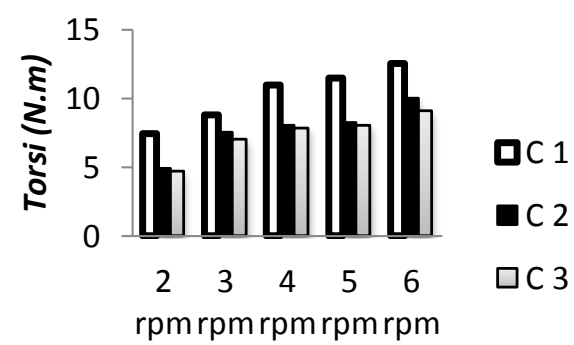

Putaran mesin 1 x 1000

Gambar 2. Grafik torsi per kenaikan putaran

Grafik di atas menunjukkan besarnya nilai torsi pada campuran 1 dengan 
perbandingan 1:4, pada putaran $2000 \mathrm{rpm}$ menghasilkan torsi 7,45 N.m sedangkan pada putaran tertinggi $6000 \mathrm{rpm}$ menghasilkan torsi sebesar 12,55 N.m. Namun, pada campuran 2 dan 3 hasil yang diperoleh dibawah campuran 1, pada putaran $2000 \mathrm{rpm}$ menghasilkan torsi 4,9 $N . m$ pada campuran 2 dengan perbandingan 2:4 dan 10 N.m pada putaran $6000 \mathrm{rpm}$. Sedangkan pada campuran 3 dengan perbandingan 3:4 menghasilkan torsi 4,70 N.m pada putaran $2000 \mathrm{rpm}$ dan 9,12 N.m pada putaran $6000 \mathrm{rpm}$.

\section{Pemakaian bahan bakar}

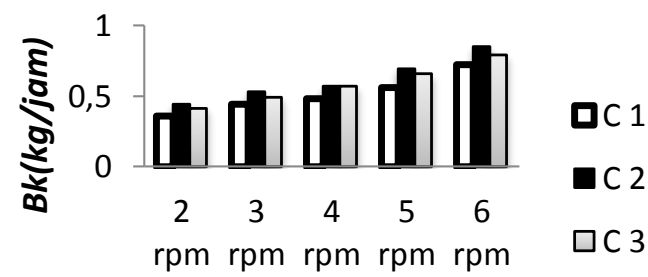

Putaran mesin 1x1000

Gambar 3. Grafik konsumsi bahan bakar

Gambar di atas menunjukkan bahwa konsumsi bahan bakar campuran 1 lebih irit dibandingkan dengan campuran 2 dan campuran 3. Pada campuran 1 putaran 2000 rpm pemakaian bahan bakarnya menghabiskan $0,36 \mathrm{~kg} / \mathrm{jam}$, sedangkan pada campuran 2 konsumsi bahan bakarnya 0,44 $\mathrm{kg} / \mathrm{jam}$ dan campuran 3 menghabiskan bahan bakar $0,41 \mathrm{~kg} / \mathrm{jam}$. Hal ini menyatakan bahwa pemakaian bahan bakar campuran 1 cenderung mempunyai tingkat efisiensi yang lebih irit dibandingkan dengan bahan bakar campuran 2 dan 3 .

\section{Daya}

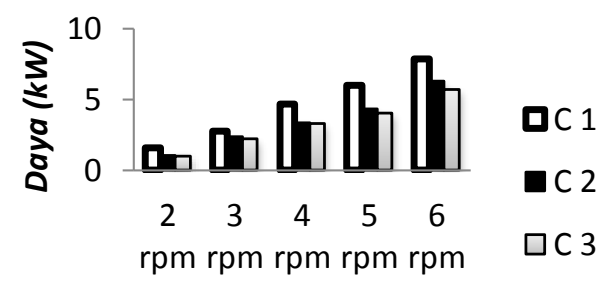

Putaran mesin 1x1000

Gambar 4 Grafik Daya keluaran
Grafik di atas menunjukkan bahwa bahan bakar campuran 1 (Perbandingan 1:4) $2000 \mathrm{rpm}-6000 \mathrm{rpm}$ menghasilkan daya yang lebih besar daripada campuran 2 dan 3 . Hal ini juga dibutuhkan pada nilai torsi yang dihasilkan. Pada putaran tinggi $6000 \mathrm{rpm}$ campuran 1 menghasilkan daya sebesar 7,88 kW. Sedangkan nilai tertinggi pada campuran 2 adalah $6,30 \mathrm{~kW}$ dan pada campuran 3 menghasilkan $5,73 \mathrm{~kW}$. Hal ini disebabkan oleh besar nilai torsi pada putaran tersebut. Dengan demikian, campuran 1 mempunyai potensi yang cukup untuk menghasilkan daya yang lebih maksimal. Selain hal tersebut, menurut penelitian Mat Agus pada tahun 2014, besarnya nilai kalor minyak plastik adalah $10968 \mathrm{kkal} / \mathrm{kg}$, nilai tersebut masih di bawah premium yaitu $11414 \mathrm{kkal} / \mathrm{kg}$. Sehingga dinyatakan wajar apabila campuran 2 dan 3 tidak dapat menghasilkan daya yang besar seperti campuran 1 .

\section{Pemakaian Bahan Bakar Spesifik}

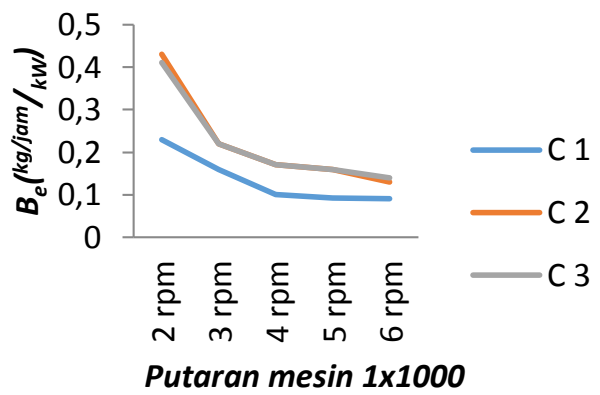

Gambar 5. Grafik Be

Pada grafik di atas terlihat bahwa pada putaran rendah pemakaian bahan bakar spesifiknya lebih tinggi dibandingkan pada putaran tinggi. Hal ini disebabkan kestabilan (konstan) pada saat pengujian tidak dapat dicapai dengan baik pada bahan bakar campuran 2 dan 3. Namun sebaliknya, campuran 1 pada grafik menunjukkan nilai lebih rendah dari campuran 2 dan 3, dengan demikian bahan bakar campuran 1 ini memiliki tingkatan efisiensi yang lebih baik dari bahan bakar yang lainnya. 
Tekanan efektif rata - rata

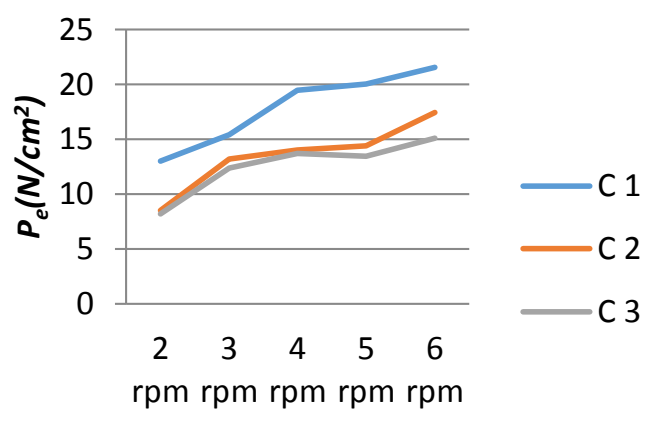

Putaran mesin 1x1000

Gambar 6. Grafik Pe

Gambar 6 menunjukkan bahwa pada saat kenaikan putaran dapat dipastikan bahwa tekanan efektif rata - rata akan naik. Kenaikan tekanan ini menunjukkan nilai yang bersangkutan dengan daya keluaran mesin. Terlihat pada grafik diatas, bahwa campuran 1 mempunyai nilai yang lebih besar daripada campuran 2 dan 3. Pada putaran 2000 tekanan rata - ratanya sebesar $13 \mathrm{~N} / \mathrm{cm}^{2}$. Sedangkan pada campuran 2 adalah 8,50 $\mathrm{N} / \mathrm{cm}^{2}$ dan campuran 3 sebesar $8,17 \mathrm{~N} / \mathrm{cm}^{2}$. Hal tersebut menyatakan bahan bakar campuran 1 lebih baik dari campuran 2 dan campuran 3 .

\section{Akselerasi}

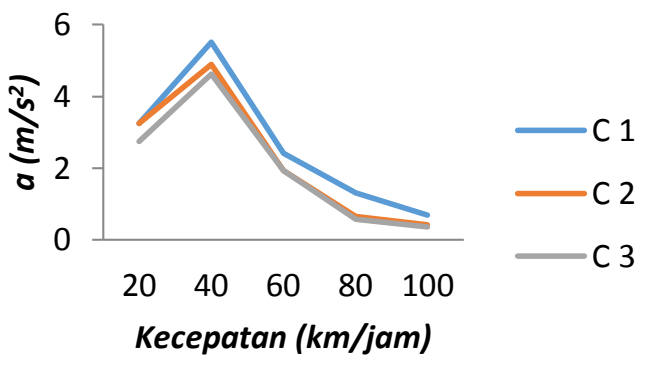

Gambar 7. Grafik Akselerasi

Gambar di atas menunjukkan bahwa pada setiap kenaikan kecepatan tidak berbanding lurus dengan pertambahan kecepatan yang konstan. Terlihat bahwa, pada kecepatan $40 \mathrm{~km} / \mathrm{jam}$ percepatan tertinggi dihasilkan oleh bahan bakar campuran 1. Namun pada kecepatan yang ditempuh selanjutnya, nilai akselerasi atau percepatannya cenderung menurun. Hal ini disebabkan oleh, transmisi pada sepeda motor ini memiliki perbandingan yang besar. Sehingga pada transmisi tersebut akan menghasilkan torsi besar namun berbanding terbalik dengan kecepatan maupun percepatannya.

\section{Perbandingan campuran 1 dan premium}

Hasil torsi yang didapatkan oleh campuran 1, yaitu campuran terbaik dalam prestasi mesin dibanding dengan campuran 2 dan 3. Di bawah ini disajikan grafik perbandingan antara bahan bakar campuran dan premium.

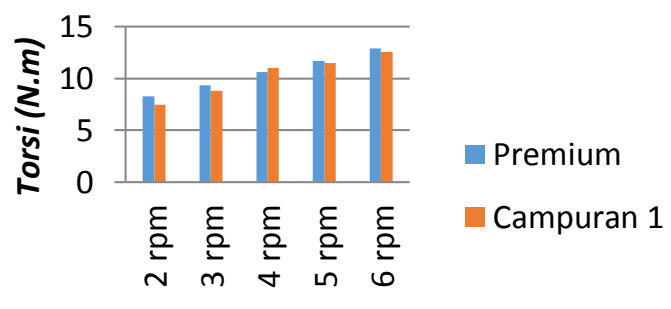

Gambar 8 Grafik perbandingan torsi premium dan campuran 1

Nilai tertinggi dari uji torsi pada campuran 1 yaitu $12,55 \quad$ N.m, diperbandingkan dengan spesifikasi teknis dari sepeda motor ini yang mempunyai nilai torsi 15,22 N.m. Maka, disimpulkan bahwa hasilnya hanya mempunyai selisih nilai 2,67 N.m. Selisih nilai tersebut dinyatakan wajar, karena perbandingan roda gigi pada kondisi ini tidak sama dengan standar pabrikan sepeda motornya. Hal tersebut dibuktikan dengan naiknya torsi pada setiap kenaikan putaran dan juga pada uji akselerasi pencapaian pada setiap kecepatan tinggi memerlukan waktu yang lebih lama. Sedangkan daya keluaran, disajikan pada grafik berikut.

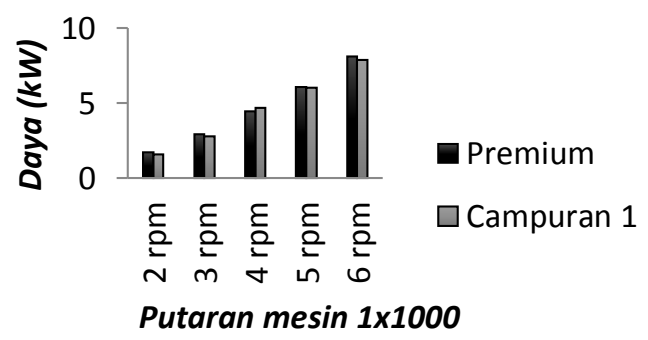

Gambar 9. Grafik perbandingan daya bahan bakar campuran 1 dan premium 
Diagram batang di atas menunjukkan angka yang siginifikan pada kedua jenis bahan bakar masing - masing. Apabila diperbandingkan dengan spesifikasi teknis pabrikan sepeda motornya yang mempunyai daya $12 \mathrm{~kW}$ nilai tersebut mempunyai selisih $3,89 \mathrm{~kW}$ untuk premium dan 4,12 kW untuk campuran 1 , kedua nilai daya yang dihasilkan tersebut mempunyai selisih 2,198 kW, apabila keduanya diperbandingkan. Sehingga selisih tersebut menyatakan bahwa campuran 1 mampu menghasilkan daya yang hampir setara dengan bahan bakar premium. Sedangkan bahan bakar spesifiknya disajikan berikut.

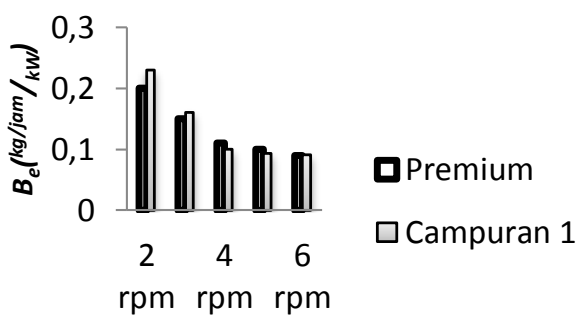

Putaran mesin

Gambar 10. Grafik perbandingan be

Diagram di atas menunjukkan bahwa campuran 1 mempunyai nilai ekonomis dalam menghasilkan daya pada pemakaian bahan bakar spesifiknya, hal ini dibuktikan bahwa konsumsinya lebih irit dibandingkan premium pada putaran tinggi. Dengan demikian campuran 1 menunjukkan nilai terbaik dalam hal efisien, namun dalam menghasilkan suatu daya bahan bakar ini lebih rendah nilainya dibandingkan premium. Untuk perbandingan akselerasi premium dan campuran 1 digambarkan sebagai berikut.

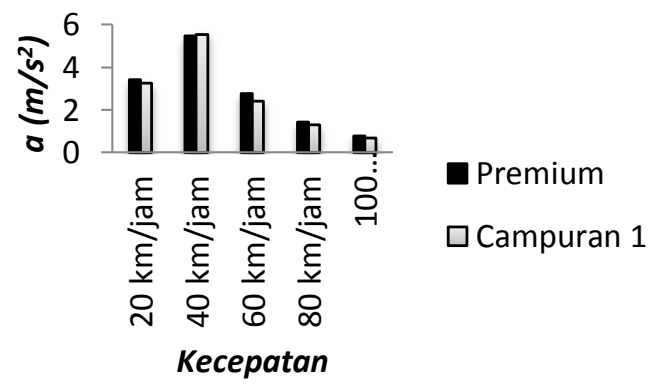

Gambar 11. Grafik perbandingan akselerasi
Grafik diatas menyatakan bahwa akselerasi yang dihasilkan bahan bakar campuran 1 sedikit lebih rendah dari bahan bakar premium.

\section{Kesimpulan}

Dari ke tiga variabel perbandingan yaitu campuran 1 (1:4), campuran 2 (2:4) dan campuran 3 (3:4), hasil keluaran daya, torsi dan akselerasi terbaik adalah pada campuran 1 dengan hasil daya $7,88 \mathrm{~kW}$, torsi 12,55 N.m dan akselerasi $5,52 \mathrm{~m} / \mathrm{s}^{2}$. Menurut hasil perbandingan bahan bakar campuran dan premium dinyatakan bahwa semakin besar perbandingan maka semakin berkurang daya keluaran, torsi dan akselerasi pada sepeda motor, hal ini dikarenakan indeks cetane minyak plastik campuran HDPE dan LDPE adalah 20, sehingga semakin besar perbandingan maka semakin besar indeks cetane bahan bakarnya

\section{Referensi}

[1] Adityo, Suryo, A.W, 2011. Studi Sifat Minyak Pirolisis Campuran Sampah Biomassa dan Sampah Plastik Prolypropylene (PP). Fakultas Teknik, Universitas Sebelas Maret, Surakarta.

[2] Mat Agus, 2014. Analisis Proximate Minyak Plastik Dengan Variasi Temperatur dan Bahan Baku Sampah Plastik dengan dua kali pirolisis. Skripsi, Teknik Mesin, Fakultas Teknik, Universitas Muhammadiyah Metro.

[3] Arismunandar Wiranto.1980.Pengger ak Mula, Motor Bakar Torak Edisi 3.Institut Teknologi Bandung; Bandung.

[4] UTF. 2014.Analisa Kerja Motor 4 Langkah. Jurnal Ilmiah Teknik Mesin.

[5] E. Karyanto,.2002.Panduan Reparasi Mesin Diesel (Dasar Operasi Servis). Pedoman Ilmu Jaya; Jakarta. 
[6] Didi, Nuryadi.2005.Fisika SMA, Kelas X Semester 1 dan 2. Gunung Pesagi; Bandar Lampung.

[7] Joko, Santoso,2010. Uji Sifat Minyak Pirolisis Dan Uji Performasi Kompor Berbahan Bakar Minyak Pirolisis Dari Sampah Plastik. 